\title{
The Benefits of Research for Academic Librarians and the Institutions They Serve
}

\section{Dale S. Montanelli and Patricia F. Stenstrom}

Although some academic librarians, administrators, and teaching faculty have expressed concern that librarians cannot or should not do research, there is a growing body of literature that supports research by librarians as carrying significant benefits both to the individual librarian and to the institution served. The benefits of research include job advancement, personal recognition when no advancement is possible, improved relationships with teaching faculty, increased responsiveness to change and innovation, and better library service through shared knowledge and experience.

ince the end of the Second World War there has been a continuing, active discussion of the appropriateness and benefits of academic status for librarians in academic and research institutions. With the adoption of the ACRL standards for faculty status for research librarians in 1971, increasing concern for and emphasis on the requirement for librarians to conduct research and write scholarly articles has been expressed. ${ }^{1}$ In surveys of librarians in academic institutions, such as those by Russ Davidson and others in 1981 and 1983 , a fear or reluctance on the part of academic librarians to become involved in the research process is reported. ${ }^{2}$ Librarians argue that the twelve-month, fortyhour-per-week structure of their jobs does not allow for research initiatives. Thomas English in his 1984 survey of administra- tors' views of library personnel status has found similar concerns. ${ }^{3}$ Not only do administrators see the work of librarianship as different from that of the rest of the faculty, they see librarians as having fewer degrees of freedom, less independence, and different basic responsibilities. In an article more positive toward faculty status, M. Kathy Cook also presents the concern of some teaching faculty that librarians do "insufficient research." ${ }^{\text {"4 }}$ In contrast to these survey findings, there is a strong and growing body of literature that supports research by librarians as carrying significant benefits, both for the librarians and the institutions in which they serve.

This paper will focus on those benefits that may be considered to be of greatest importance. They include job advancement, personal recognition when no ad-

Dale S. Montanelli is Director of Administrative Services and assistant professor and Patricia F. Stenstrom is Library and Information Science Librarian and associate professor at the University of Illinois, Urbana, Illinois 61801. This paper was presented at the ACRL Fourth National Conference in Baltimore, April 9-12. 
vancement is possible, improved relationships with teaching faculty as a result of better understanding of the research process, increased responsiveness to change and openness to innovation, and better library service through shared knowledge and experience. The discussion will touch briefly upon two related topics: faculty status and librarian autonomy. While both faculty status and autonomy are desirable, the value of research should be seen as independent of either of these issues.

There are two reasons that research is beneficial to the individual librarian. First, research promotes advancement and second, it provides recognition when advancement is not possible. Paula Watson comments on the preponderance of administrators, branch librarians, and department heads as library publishers. ${ }^{5}$ She states that "it was possible that most librarians in the study: administrative, branch librarians, and the department heads have gained their positions of responsibility because they are more competent and motivated than other professionals. It may also be due to the autonomy which librarians in these positions have traditionally enjoyed." Whatever the reason, study after study indicates that successful librarians, as measured by professional advancement, publish more than their less successful counterparts. Dorothy Anderson compares Council on Library Resources senior fellows (who were defined as being library leaders) with both a matched group and a control group of ACRL members. ${ }^{6}$ She finds that senior fellows reported more than twice as many publications, speeches, and courses taught as the ACRL matched group and nearly three times as many as the ACRL control group. This study shows "those academic librarians considered successful by their selection as senior fellows published dramatically more than a control group of academic librarians." The study finds that leaders in academic librarianship, whether male or female, started earlier, published more, spoke and taught more, and moved more often than their peers. These findings suggest that publishing is viewed by librarians themselves as important in obtaining promotion and job advancement, Librarians become leaders because they publish more rather than the reverse.

In a recent study contracted by the Office of Library Personnel Resources, Ellen Bernstein and John Leach find that librarians indicated that recognition meant more to them than financial reward.? The same study reveals a concern for lack of job mobility and advancement. Publishing provides an alternative route to hierarchical advancement for recognition. In those academic libraries with faculty status this recognition may take the form both of financial and status rewards.

Allen Veaner worries that librarians are leaving the profession because of frustration and boredom, "burning out" as a result of the repetitive nature of their jobs. ${ }^{8}$ He hypothesizes that what is missing is autonomy and opportunity to develop creatively. Writing on the quality of work life, Charles Martell identifies six characteristics that should be included in the employee's work:

- autonomy

- challenge

- expression of creativity

- opportunity for learning

- participation in decision making

- use of variety of valued skills and abilities

The inclusion of research in the work life of academic librarians satisfies all of these requirements and provides the stimulus that Veaner claims is missing.

In addition to the benefits reported for the individual librarian, there are clear advantages for the institution and the profession; chief among these are improved relationships with teaching faculty, increased responsiveness to change, and better library service.

In a 1981 analysis of the relationship between librarians and teaching faculty, Mary Biggs points out that "present day advocacy of 'subject specialists' and 'second master's degrees' implicitly recognizes the problem of a library staff without knowledge of, and respect for, books and methods of scholarly investigation. ${ }^{10}$ While this statement may be too strong an indictment of library education, it does serve to identify a problem of credibility 
that librarians often confront. Other studies, such as the previously mentioned one by Cook, reveal an ambiguous attitude on the part of teaching faculty toward librarians.

Even faculty members with the greatest goodwill are not strongly convinced of the importance of the librarian in their use of the library. While urging the need for a changed image for librarians, Richard Halsey defines the profile of the twentiethcentury librarian as that of a "docile golden retriever." 11 Veaner also cites the image of the librarian as a passive keeper or custodian of materials rather than as a dynamic force in the creation and organization of knowledge. ${ }^{12}$ How much better in combating this image of passive, docile inactivity to have proof of knowledge of methods of scholarly investigation and an image that shows dynamic organization and leadership developed through a record of research and publication. Whether such publication occurs in the field of librarianship or in the subject field in which the librarian chooses to work, this knowledge of research methods will translate into better service to the other scholarly users of the library.

One of the hallmarks of librarianship in the $1980 \mathrm{~s}$ is the need for dynamic reaction to change. John Naisbitt reports that "change is occurring so rapidly that there is no time to react; instead we must anticipate the future. ${ }^{\prime 13}$ JoAnne Hall suggests that librarians who are involved in research perceive themselves to possess managerial and leadership skills, and, in fact, research activity was found to be a significant factor in receptivity to change. Hall speculates that the reading of library literature might achieve the same results as doing research. ${ }^{14}$ But what are the incentives to read library literature, and once read, to apply rigorous evaluative and analytic judgments to the reading? Research requires an active questioning approach, exactly the approach needed to anticipate change.

Research in many areas of librarianship is needed as a number of our library "seers" have mentioned when looking into future issues. Biggs herself points out that the increasingly complex nature of library activities requires research. And Martell calls for creative responses to the dramatic changes we are encountering in the "knowledge society." ${ }^{15} \mathrm{He}$ suggests that library bureaucracies make room for the research-and-development function that is necessary for libraries to deal with change and with requirements that campuses will place on them in the future. Academic libraries need active programs of research and publication. They need to share their experience and gain from each other. It is better for these topics to be handled by professional librarians working in academic environments with patrons and administrations than for outside research agencies to be hired on contract to do the work that librarians should be doing for themselves.

One of the excuses frequently given as a reason why librarians cannot be expected to carry out research is because they do not have the flexible schedules that members of the teaching faculty have. In a dynamic library environment, no professional librarian is chained to a work station in the manner that books were chained to tables in the twelfth century. The conception that teaching faculty have unlimited free and flexible time is, in fact, a misconception. Studies of faculty use of time conducted at major research universities indicated that faculty spend between fifty and sixty hours a week in teaching and research-related activities. ${ }^{16}$ Work in the academic community is not a time-clockoriented, forty-hour-a-week job. Academic librarians should have freedom to manipulate their schedules such that all aspects of the work get done and all responsibilities are met.

The other negative myth surrounding research is that service will suffer because excellent librarians will not receive tenure. English refers to the supurb reference librarian who has been terminated for failing to meet traditional faculty requirements. Substitute political science professor or education professor for reference librarian, and you will have the 1970 s campus newspaper headlines from every research university in the country. Re- 
quirements for research for librarians will vary depending on comparable levels of research in the institution that the library serves. There will always be the outstanding librarian who cannot or will not conduct research, but this also is true for the teaching faculty-research and good teaching are not, however, mutually exclusive.

We live in an era that emphasizes both competition and competency. These are difficult but exciting times. Research can help us.

\section{REFERENCES}

1. "Standards for Faculty Status for College and University Librarians," College and Research Libraries News, 8:210-12 (Sept. 1972).

2. Russ Davidson, Connie Capers Thorson, and Margo C. Trumpter, "Faculty Status for Librarians in the Rocky Mountain Region: A Review and Analysis," College \& Research Libraries 42, no.3:203-13 (May 1981); Russ Davidson; Connie Capers Thorson; and Diane Stine, "Faculty Status for Librarians: Querying the Troops," College \& Research Libraries 44, no.6:414-20 (Nov. 1983).

3. Thomas G. English, "Administrators' Views of Library Personnel Status," College \& Research Libraries 45, no.3:189-95 (May 1984).

4. M. Kathy Cook, "Rank, Status and Contribution of Academic Librarians as Perceived by the Teaching Faculty at Southern Illinois University, Carbondale,"' College \& Research Libraries 42, no.3:214-23 (May 1981).

5. Paula DeSimone Watson, "Publication Activity among Academic Librarians," College \& Research Libraries 38, no.5:375-84 (Sept. 1977).

6. Dorothy J. Anderson, "Comparative Career Profiles of Academic Librarians: Are Leaders Different?" The Journal of Academic Librarianship 10, no.6:326-32.

7. Ellen Bernstein and John Leach, Career Perceptions of American Librarians (Chicago: American Library Assn., Off. for Library Personnel Resources, 1985).

8. Allen B. Veaner, "1985 to 1995: The Next Decade in Academic Librarianship, Part I," College \& Research Libraries 46, no.3:209-29 (May 1985).

9. Charles Martell, "QWL Strategies: People Are the Castle, People Are the Walls, People Are the Moat," Journal of Academic Librarianship 10, no.6:350-54 (Jan. 1985).

10. Mary Biggs, "Sources of Tension and Conflict between Librarians and Faculty," Journal of Higher Education 52, no.2:182-201.

11. Richard S. Halsey, "Recall-Research-Renewal: A Message of Necessity for the University Library," in Future of Libraries (Albany, N.Y.: University Libraries, State Univ. of New York 1982). Panel discussion by librarians, administrators, faculty and students.

12. Allen B. Veaner, "1985 to 1995: The Next Decade in Academic Librarianship Part II," College \& Research Libraries 46, no.4:295-308 (July 1985).

13. John Naisbitt, Megatrends (New York: Warner, 1984).

14. JoAnne Hall, The Relationship beteween Innovation or Change Agent Characteristics of Academic Librarians in the Southeastern United States (Ph.D. diss., Univ. of Michigan, 1984).

15. Charles Martell, "Editorial: Creative Behavior in Libraries," College \& Research Libraries 46, no.4:293-94 (July 1985).

16. John Terwilliger, Office of Administrative Studies, Univ. of Illinois at Urbana-Champaign, personal communication (July 1, 1985). 